Originalni naučni rad

UDK: $343.983: 547.963 .3$

Primljen: 3. 7. 2018.

Prihvaćen: 13. 9. 2018.

doi:10.5937/nabepo23-18139

\title{
SOME APPLICATIONS OF DNA DATABANKS AS AN INVESTIGATIVE TOOL FOR SOLVING CRIMINAL CASES ${ }^{1}$
}

\author{
Francesc Mestres $^{2}$ \\ University of Barcelona, Department of Genetics, Spain \\ Goran Živanović ${ }^{3}$ \\ University of Belgrade, Department of Genetics \\ Institute for Biological Research "Siniša Stankovič"
}

\begin{abstract}
The introduction of molecular markers, such as STR (Short Tandem Repeats), was a fundamental event in Forensic Genetics. It was possible to obtain individual genetic profiles that allowed to properly identify individuals with small probability of error. Furthermore, police officers soon discovered the investigative value provided by DNA databanks, defined as a collection of individual DNA profiles usually used to investigate crimes and identify suspects. In this article, the authors present the most common use of these police databanks, comment their drawbacks and how to overcome them. The usage and value of police DNA databanks in special criminal situations are also explained: cold cases, familial searches and dragnets. These three particular
\end{abstract}

\footnotetext{
1 This manuscript was supported by the following grants: Ministerio de Economía y Competitividad, Spain (CTM2017-88080) and the Generalitat de Catalunya, Spain (2017 SGR 1120). We thank Dr. Andrea Izquierdo-Bouldstridge PhD (Parc Científic de Barcelona, Barcelona, Spain) for corrections to the English.

2 fmestres@ub.edu.

3 goranziv@ibiss.bg.ac.rs.
} 
situations are described and commented in this article. In summary, although several technical, ethical-legal and international aspects have to be improved, police DNA databanks are really powerful investigation tools that allow solving a large number of criminal cases.

Keywords: Forensic Genetics, DNA profile, DNA databank, cold case, familial search, dragnet.

\section{Introduction}

In the early 1990s the introduction of Short Tandem Repeats (STR) as DNA markers was a giant step forward in Forensic Sciences. They are repeat units that are 2-6 base pairs long and the number of repetitions defines the different alleles (Butler, 2005). Although other molecular markers were first introduced in Forensic Genetics as VNTR (Variable Number of Tandem Repeats) (Jeffreys, Wilson, Thein, 1985), which allowed solving the Sarbah (Jeffreys, Brookfield, Semeonoff, 1985) and Pitchfork (Jeffreys, 2005) cases in the 1980s, STRs are popular due to their intrinsic characteristics: they present a large number of alleles per locus, the amplicons obtained are rather short length and multiplexing analysis is possible (Butler, 2012). Thus by using them, it is possible to generate highly discriminant results, successfully study sample mixtures, analyse degraded materials, save time and reduce economical costs. For these reasons, to obtain a STR genetic profile from a biological stain recovered at a crime scene and to positively identify a suspect was a crucial landmark in criminal investigation. In many cases, this identification was even considered the regina probatorum or the queen of the evidence. Furthermore, police officers discovered that STR markers were not only useful to corroborate the classical investigation, but DNA could be a direct investigative tool to find potential suspect in cases where no information was available on the perpetrator. This was the fundamental principle to constitute the police DNA databanks, because criminals tend to re-offend, the severity of crimes increases with the offender's age and rather a small number of delinquents is responsible for a large number of crimes (Goodwin, Linacre, Hadi, 2007). Furthermore, DNA databanks are involved in other particular investigative approaches, such as family searching (to find a family member of the offender) and dragnets (obtaining a large collection of profiles of people from a geographic region). Our main aim in this article is to present the different application possibilities in criminal investigation of the information gathered in these databanks.

First at all, we would like to introduce a terminological topic. It is true that DNA databanks and DNA databases are commonly used as synonymous 
expressions, the second one being the most popular in the literature, and was selected to name the first collection of DNA profiles, the United Kingdom National DNA Database (UK NDNAD) which was established in 1995 (Werrett, 1997; Schneider, Martin, 2001; Gill, Fereday, Morling, Schneider, 2006a; Gill, Haned, Bleka, Hansson, Dorum, Egeland, 2015; Barash et al., 2012; Machado, Silva, 2016; Benschop et al., 2017). We think that it is possible to take advantage of both terms to differentiate two different key concepts involved in Forensic Genetics investigation. Thus, following the terminology of a DNA databank proposed by different authors (Harbison, Hamilton, Walsh, 2001; Bieber, 2006; Michaelis, Flanders, Wulff, 2008; Mestres, Vives-Rego, 2009; Krimsky, Simoncelli, 2011), it is defined as a collection of individual DNA profiles used to investigate crimes and identify suspects. There are other DNA databanks for forensics purposes, as those generated after a mass disaster containing genetic profiles from the victims and their family members. Their purpose is to identify the human remains recovered after the disaster. In similar way, there are DNA databanks for the identification of missing persons or people buried in a common grave as a consequence of a war. Although these humanitarian situations are also interesting from a forensic point of view, our aim in this article is to focus only on criminal DNA databanks. On the other hand, a DNA database would be a collection of allele frequencies used to provide estimates of how rare a particular DNA profile is in a population of reference (Buckleton, Bright, Curran, Taylor, 2016). This later information is extremely valuable to properly compute the random match probability defined as the likelihood that two unrelated persons share the same genotype (Fung, Hu, 2008). We consider that this differentiation could be useful to differentiate both types of data collections.

An interesting question is why a DNA databank is to be constructed. According to an analysis developed in the UK (Busher, 2002; Goodwin et al., 2007), there are different reasons: (1) Criminals tend to re-offend - for instance, $90 \%$ of rapists and $50 \%$ of armed robbers have had a previous arrest; (2) The severity of crime often tends to increase - usually, criminal activity starts at a young age with many criminals committing the first offence between 16 and 19 years of age; (3) In general, a small number of offenders can be responsible for a large number of crimes - linking these crimes together can aid police investigations. This is particularly valuable for burglaries, sexual assaults, etc. Thus, controlling these offenders would make possible to decrease the country's criminality. For this purpose the UK NDNAD (United Kingdom National DNA Database) was established in 1995 (Werrett, 1997; Wallace, 2006). It was functional shortly after the introduction of the genetic profiling using 6 STR loci by the Forensic Science Service of this country. It is worth remembering that STRs (also known as microsatellites) are genetic markers consisting of a unit of a few nucleotides repeated a large number of times adjacent 
to each other on the DNA strand (Butler, 2005, 2010). There are thousands of these markers located along the whole human genome (Strachan, Read, 2011). For each locus individually, different alleles are defined as the number of repetitions. Importantly ethical, legal, operative and social question soon arose about the use of DNA databanks (Dundes, 2001; Reilly, 2001; Gamero, Romero, Peralta, Carvalho, Corte-Real, 2007; Gamero et al., 2008; Van Camp, Dierickx, 2008). For instance, which profiles have to be included? And from this question, we can generate others, should only genetic profiles obtained from very dangerous offenders be included? In the case of misdemeanours, do criminals have the obligation to donate their DNA and their genetic profile to a databank? Does every citizen has to donate their own DNA to the national databank? Should the genetic profiles be kept in a databank for a limited time (10-20 years)? After the death of a person, should their genetic profile be deleted from a databank? The original criterion in the UK for addition of a genetic profile from an individual to the NDNAD was that the person had been arrested for an offense punishable by imprisonment. However, in 2001 the Criminal Evidence Act allowed samples to be retained in the NDNAD even if the individual was found not guilty at the trial. In 2003, some police chiefs and politicians suggested that everybody's DNA samples in the UK should be included in the NDNAD. Finally, it is worth considering that the European Court of Human Rights stated in 2008 that "retention of fingerprints, cellular samples, and DNA profiles after criminal proceedings were terminated by an acquittal" (Asplen, 2014). In summary, each country using DNA databanks has its own legal framework, but it has to adapt also to the international rules.

From an informatics point of view, the operation of DNA databanks is rather simple. Appropriate software was developed from the beginning and the instructed operators were to man the computers. Each country has their confidentiality rules and everyone involved in the informatics searches has to follow them strictly (Comisión Nacional para el uso forense del ADN, 2011). The amount of genetic profile data introduced in police databanks increased rapidly. For instance in 2017, the UK NDNAD contained about 6.15 million profiles (National DNA Database statistics, 2017), and the Chinese databank over 13.50 million (Walsh, Bright, Buckleton, 2016). The National DNA Index (NDIS) statistics of the USA gives also an idea of the magnitude and usefulness of CODIS (Combined DNA Index System) databank (CODIS - NDIS Statistics, 2018). There are two sources of data: the profiles generated from evidence (blood, semen, saliva, etc.) that have been collected from crime scenes and the profiles generated from individuals (they were obtained from identified individuals as convicts, suspects, volunteers, etc.). Each time that a new genetic profile is introduced in the databank there are three types of potential concordance (the so called 'hit' or 'match'): crime scene to suspect (it is possible to identify the offender), crime scene to crime scene (it is not possible to identify 
the offender, but the same individual's biological material was recovered from both crime scenes) and finally suspect to suspect (only when individuals have given incorrect details to the police about their identity). The use of DNA databanks has produced excellent results in all countries that have introduced them (Asplen, 2014). However, there are some weak points. When a 'match' is obtained, police officers have to properly investigate the suspect and the case. For instance, in 1999 in the Manchester area a house was assaulted and the burglar left DNA evidence at the crime scene (Goodwin et al., 2007). At that time, 6 STR loci were used and the random match probability was considered low enough. The genetic profile from this crime scene was introduced in the NDNAD and a 'match' was obtained. The individual (Mr R. Easton) was automatically arrested by the police, although he suffered from Parkinson's disease, his home was located $200 \mathrm{~km}$ far from the crime scene and he had a good alibi. The probability to find the same genetic profile in the Great Britain population was estimated as 1 in 37 million. Finally, using additional STRs it was possible to deduce that $\mathrm{Mr} \mathrm{R}$. Easton was not the perpetrator. To avoid this kind of situation, the number of STRs analysed has been progressively increasing. When the FBI introduced CODIS in 1997, it contained 13 STR loci, of which many were initially developed by the Forensic Science Service (UK). With the information provided by the combination of genetic markers of CODIS, the random match probability (defined as the probability to find a particular profile in a reference population among no related individuals) is about 10 ${ }^{19}$. The STR loci used by CODIS system were adopted by different European countries. This is a valuable strategy to carry out international searches using the DNA databanks of different countries. However, many countries have particular STR loci, as Germany and Austria (Wiegand, Budowle, Rand, Brinkmann, 1993; Butler, 2012), and then only those STR loci in common between countries can be compared. In Europe, two main working groups are trying to unify the STR loci and other aspects of Forensic Genetics: the European Network of Forensic Institutes (ENFSI) (ENFSI DNA Working Group, 2017) and the European DNA Profiling (EDNAP) Group (Gill, Fereday, Morling, Schneider, 2006b). Also, political and judicial agreements are needed between the countries to allow this kind of searches. Currently, more genetic markers are being introduced to avoid incorrect identifications in databanks, for instance, the recent kit PowerPlex (C) Fusion System (Promega Corporation) allows the analysis of 24 STR loci which meets the European and CODIS standards. Another weak point is the so called 'secondary DNA transfer'. It may be possible that a person alien to an offense could leave small amounts of his/her DNA on the crime scene. As the PCR reaction is able to amplify very low amounts of DNA, these traces could produce a full genetic profile and be compared with those introduced in a police databank. The search will be of a person not related to the crime, but his/her DNA was present at the crime scene due 
to the secondary DNA transfer. In 1997, this possibility was evaluated by van Oorschot and Jones (1997), but was considered rather improbable. However, in 2013 the millionaire Mr R. Kumra was killed in California (Cale, 2015; Cale, Earll, Latham, Bush, 2016). From his fingernails forensic police officers (also known as scientific police officers in countries as France, Spain or Portugal) recovered DNA and assumed it was from the murderer. The genetic profile obtained was compared with those in the databanks and a match was found: $\mathrm{Mr}$ L. Anderson. He was arrested and held for four months with murder charges. Luckily, he had an alibi: when the victim was killed he was at the hospital drunk and unconscious. Probably, the secondary DNA transfer was mediated by the paramedics, who first attended Anderson and later went to the Kumra's mansion without changing their gloves.

In any case, the police DNA databanks are an excellent tool, which has helped to solve a wide range of crime types. For instance, the new Irish databank, operative from the November 20, 2015 has allowed to link suspects with crime scenes, solving a large number of cases (Feehan, 2016). It was even possible to relate a particular burglar with fourteen different crime scenes. Thus, the effectiveness of the DNA databank introduction was tremendous. However, after the introduction success, the number of hits is expected to reach a plateau and then remain rather stable (Walsh et al., 2016). In summary, the efficiency of police DNA databanks is demonstrated over and over and their benefits are clear (Walsh, Curran, Buckleton, 2010).

\section{Cold Cases}

Any case whose evidentiary clues of investigation have been exhausted is defined as a cold case (Heurich, 2008). It does not always have to be old, because one case could be considered cold even if it is only several months old. However, all these cases are not forgotten and "historical" ones have benefited from the new DNA technologies and the individual genetic profiles stored in DNA databanks (Ashcroft, Daniels, Hart, 2002). These cases have to be prioritized according to different criteria such as the availability of victims, suspects, witnesses, physical evidence and the possibility to re-analyse the crime scene and related recorded documents (Schuster, 2008). It is possible to re-analyse the evidence collected many years ago, to obtain and analyse DNA from the suspect and to search the profile obtained among those kept in police databanks. Thus for cold cases research, it is important to keep the evidence properly stored. Also, it must be taken into account that accidental contamination may be possible. For instance, we must remember that the forensic police officers began to wear gloves at the end of the nineties. The introduction of DNA 
databanks has been a crucial element to successfully resolve a large number of major cold crimes (Hunter, 2010). Furthermore, we must not forget the effect of databanks in crime prevention (Lovrich et al., 2004).

There are many examples highlighting the role of DNA databanks solving cold cases and they can be obtained from journals, newspapers and internet webpages. However, we want to present several cases that we consider they could exemplify the value of this investigative method. The first example was a cold case from 1969 (Goodwin et al., 2007). Roy Tutill (aged 14) was sexually assaulted and strangled in a woodland near Laetherhead (United Kingdom). The case remained unsolved until 2001, when Forensic Science Service analysed several pieces of clothes of the boy using novel DNA techniques and obtained a partial DNA profile. Using the UK NDNAD a match was obtained. The profile corresponded to $\mathrm{Mr}$ B. Field, who was arrested two years earlier because he was driving under the influence of alcohol. In the UK, this offence implies the donation of DNA to police. More samples were recovered and a full match was obtained. Mr Field pleaded guilty of the murder of Roy Tutill and he was also investigated for other crimes. In France, during the years from 1986 to 1997, twelve girls and young women between 13 and 22 years of age disappeared along the A-6 highway (Le Parisien webpage, 2014). The mother of one of them insisted on reopening the case and using the then available DNA techniques. Forensic police obtained the aggressor's DNA profile from one of the victim's clothes. Using the French police databank the murderer was identified and arrested in 2014 (Mr P. Jardin). Another interesting case took place in Australia (Grant, 2010). In 2001, two robbers assaulted the rural home of Mrs F. Olson (aged 71). When forensic police studied the crime scene they found a bloated leech on the floor. Neither Mrs F. Olson nor police officers had been bitten by a leech, and policemen concluded that the animal had dropped from one of the criminals. It was possible to analyse the human blood from the leech and a DNA profile was obtained. In 2009, Tasmanian Police arrested Mr P. Cannon on drug charges. He had to donate his DNA and it matched with that obtained from the leech. He pled guilty and the eight-year cold case was solved. In Tarragona (about $90 \mathrm{~km}$ south of Barcelona, Spain) an old case of robbery with murder (2002) was finally solved in 2012 by the Cuerpo Nacional de Policía using the DNA obtained from a murderer's hair and comparing this genetic profile with those stored in the Spanish police databank (Tarín, 2012). The international cooperation in this area is also important. For example, in 2002 a man was found tortured and killed in Gavà (about $18 \mathrm{~km}$ south of Barcelona, Spain). At the crime scene, his killers (they were three Romanian citizens) left their DNA in cigarette butts, glasses, cups and even under the victim's nails (Figueredo, 2013). The cooperation with French and German police services, by means of DNA databanks from these countries, was very effective identifying and arresting the offenders in 2012. Finally, we present a 
case where it was possible to obtain a genetic profile from a very small amount of DNA. In April 2013, a criminal gang kidnapped the manager of a Parisian jewellery store (Europe 1 webpage, 2014). They wanted the security codes of the store and threatened to burn her with a flammable liquid. Obviously, they got the codes and robbed the jewellery while one of them guarded the manager. After the robbery, she was very anxious and the keeper kissed her before releasing her. French forensic police obtained the genetic profile of the suspect using the DNA recovered from the manager's cheek. In January 2014, he was identified by the French DNA databank while he was in prison for another offence. We want to point out two important conclusions: (1) a criminal must always remember that probably he will be finally identified and arrested; (2) People have to be confident in their police and judicial system, because even the more horrible crimes can be finally solved and the offenders punished.

\section{Familial DNA Searches}

When CODIS system was introduced in the USA, proper software was also developed to operate with the databanks. For instance, it was possible to carry out a search for 'imperfect' matches (Krimsky, Simoncelli, 2011). This procedure allowed to search for incomplete or partial matches, a situation that could be due to DNA partially degraded, mixtures of two or more DNA profiles, allele dropout or failure to amplify an allele and even mistyping when a genetic profile was introduced in the DNA databanks. CODIS users introduced the term "search stringencies" and they can be of three types defined as: (A) High stringency: all alleles of the loci that are present in both DNA profiles that are compared are identical. For instance considering a single locus, one DNA profile with STR alleles 8, 11 will generate a match with another profile with alleles 8,11 . (B) Moderate stringency: in this case the alleles of a locus (among two DNA profiles) with the least number of distinct alleles must be present in the corresponding locus of the other DNA profile. For example: under moderate stringency condition one profile with STR alleles 8,11 will generate a match with another profile with STR alleles 11,11 . Thus, the heterozygote 8 , 11 is deemed a moderate stringency with the homozygote 11, 11. (C) Finally, in the case of low stringency each locus that is compared between two genetic profiles must have at least one allele of that locus present in the other profile. For example: a STR with alleles 8,11 presents a low stringency match with STR 5, 8 .

Investigators realized that this software could be used for so called "familial searches". This procedure is based on two premises: first, close matches in DNA profiles are more likely to indicate that sources of the DNA are close 
family members than two unrelated individuals. Second, the closer the DNA match is, the higher is the likelihood that the individuals are related. For this reason, if we study the core of CODIS system (13 autosomic STR loci), siblings (on average) have about 18 of the 26 alleles in common. However, unrelated individuals on average have about 8 out of 26 in common. According to these criteria of partial match, the first degree relatives (parents or siblings) are expected on average to share about $50 \%$ of one another's DNA variants. In the particular case of a father (or mother) and a child, DNA profiles match at no fewer than 13 alleles, and most importantly, they share at least one allele at each locus. Shared alleles decrease rapidly in the second $(25 \%)$ and the third (12.5\%) degree relatives. In these latter cases, the presence of rare alleles, found in very low frequencies in the population, can be very valuable.

Thus, in some cases the suspect is not directly identified in the DNA databanks, but it is possible to detect his/her familiar group and then redirect the police investigation. However, the 'familial search' can miss potential relatives (false negatives) or falsely identified unrelated individuals (false positives). Let us illustrate this point with a simple computation: the chance that two unrelated individuals match at 13 or more sites with every marker having one match (as in the situation that occurs in the parent-child pairs) is $1 / 2000$. However, police databanks can have millions of genetic profiles, and for this reason, generating thousands of false positives. In order to minimize the possible mistakes, likelihood methods are used to evaluate the possible familiar relationship. Likelihood ratios are obtained contrasting the probability of the observed genetic profiles given proposed familiar relationships versus the probability of observing the genetic profiles if the donor of the evidence and the identified partially matching profile sources are unrelated. Finally, the use of 'familial search' produces legal and ethical problems. This investigative approach invades the privacy of innocent people, could generate problems inside families, many suspicious persons are innocent and individuals are investigated when there is any evidence to relate them with the investigated crime. For these reasons, there are ethic and legal concerns for supporting this kind of searches (Bieber, Brenner, Lazer, 2006; Suter, 2010; Kim, Mammo, Siegel, Katsanis, 2011; Barca, 2013; Innocence Project, 2016; García, Crespillo, Yurrebaso, 2017).

Although 'familial searches' present some difficulties, as a large collection of potential suspects is usually obtained or in several cases the actual suspect is not detected, they have been very valuable to solve major crimes. For instance, one of the early cases solved by this procedure was in 2003 (BBC News webpage, 2004): the impact of the brick in the windscreen of a truck caused a fatal heart attack to its driver ( $\mathrm{Mr} \mathrm{M}$. Little). Using this novel approach it was possible to arrest $\mathrm{Mr} \mathrm{C}$. Harman, accused of dropping the brick from a footbridge 
over the M3 motorway (west of London). In 2010, the LA Police was able to identify and arrest the serial killer 'Grim Sleeper' who acted in the south Los Angeles area in the 1980s (Miller, 2010). In 2008, a search in databanks using the genetic profile of the serial killer was negative. However, a potential partial match was observed in 2010: a young man named Christopher Franklin was convicted on a felony weapons charge. For the matched alleles, he was probably the son of 'Grim Sleeper'. Police officers began to investigate and follow $\mathrm{Mr}$ Lonnie Franklin (Christopher's father). One day, he discarded a piece of pizza and according to the USA legislation police can analyse all items discarded by a suspect without a judicial warrant. It was possible to obtain a DNA profile that matched with that of 'Grim Sleeper'. Thus, a cold case was solved by a 'familial search'. Other cases are the 'Loner', a case solved in 2003 where a rare allele variant was the key element, or the 'Shoe Rapist' arrested in 2006 using a partial match of his sister. In summary, familial searches are a powerful tool to capture criminals, invigorate cold cases and exonerate unfairly condemned individuals. However, they cause a considerable impact due to personal and family intrusion of a large number of individuals.

\section{Dragnets}

When police investigators have no suspects and common police DNA databanks do not produce a match, it is possible to carry out a dragnet. It is defined as a situation where police officers ask a number of individuals (usually large) to voluntarily donate DNA samples and construct a particular police DNA databank in an effort to identify the perpetrator of a crime or a crime series. The main aim of the dragnet is to obtain a suspect when there is none. It is worth pointing out that the first criminal case solved by using DNA genotyping (Pitchfork case of 1987) was historically the first dragnet. More than 4,580 males from Leicestershire (United Kingdom) were genotyped (Jeffreys, 2005; Kaye, 2010). Colin Pitchfork tried to avoid the analysis, but was finally detected and had to donate his DNA. Finally, he pleaded guilty of the murders. In general, dragnets are very expensive and ineffective (Walker, 2004; Esmaili, 2007; Krimsky, 2011), because the perpetrator usually left the area before the dragnet began. However, combined with a familial search could bring new insights in a criminal case. Nevertheless, there are many concerns regarding civil liberties: usually they are carried out without a judicial warrant, probable cause or individual suspicion; somehow police generate coercion to obtain samples; a person is considered suspect if he or she refuses to give his or her DNA and the person has the right to privacy; finally, the DNA databank generated by the dragnet must be used only for investigate the present 
case, not for future searches (Rothstein, Carnahan, 2001; Cho, Sankar, 2004; Fernandez, 2005; Simoncelli, Krismky, 2007; Zadok, 2010). One of the largest dragnets took place in Cloppenburg (Germany). In 1998, 16,400 local men from this town and surroundings were genotyped, because police looked for a serial rapist and murderer. Finally, a suspect was arrested after he voluntarily supplied samples for DNA testing, and his genetic profile fitted those recovered at the crime scene. Other dragnets were (Krimsky, Simoncelli, 2011): Miami (Florida) in 1994, police were haunting a serial killer and 2,300 males were analysed; Yate (UK) in 1995, for searching a killer, about 4,500 men were genotyped; Chipping Sodbury (UK) in 1996, over 4,500 men were sampled for detecting the killers of a man; Baton Rouge (Louisiana) in 2002, in the hunting for a serial killer, 600 men were genotyped. Even, a cold case was solved by means of a dragnet (NCR.nl webpage, 2012). In 1999, M. Vaatstra, a 16 years old girl, was killed in Oudwoude (The Netherlands). It was difficult to find the murderer by classical police methods and DNA analyses discarded the initial suspects. Vaatstra's family asked for a dragnet and the police agreed with the idea because a partial match could maybe be produced (a familial case). Incredibly, a full match was obtained from a farmer who voluntarily donated his DNA (Mr Japer S.) and he confessed he was the killer. Finally, one of the last large dragnets began in autumn 2015 in the Swiss canton of Lucerne (Swissinfo.ch webpage, 2015). A young woman was pulled off her bike at night and raped. Due to the violent fall from her bike she is now paralyzed. Policemen obtained the perpetrator's DNA, but no match was obtained from DNA databanks. Based on the description of the offender by the victim, 372 males were genotyped. Until now, no match has been obtained.

In summary, DNA dragnets are not the best investigative approach due to their cost and possible civil liberties violations. However, in some circumstances it could be the only way to find a suspect of horrible crimes. Even in these exceptional situations, DNA dragnets must be conducted scrupulously according to the country's rules. Finally, once the case has been closed, the DNA databank generated from volunteers must be destroyed.

\section{Conclusions}

To illustrate the possibilities of DNA analyses and police databanks we want to comment a final investigation, the Eva Blanco case (Martínez, 1997). In 1997, she was raped and killed by nineteen stabs close to Algete, near Madrid (Spain). The Guardia Civil (the Spanish police corps that carried out the investigation) obtained DNA samples from perpetrator's semen stains. There were no suspects and the DNA profile did not match the others stored in Span- 
ish police DNA databanks. A dragnet was developed and 2,013 males voluntarily donated their DNA. However, no match was produced and the case became a cold case, with the problem that it would be closed in 2017 according to Spanish legislation. Later, the judge agreed to re-analyse the perpetrator's DNA to try to deduce his ethnicity. One of the best centres in Spain, the Forensic Laboratory of Universidad de Santiago de Compostela, carried out the study and it was found that the criminal was probably a North African. With this new information the Guardia Civil officers re-directed the search. They investigated about 200 males (including DNA analyses) who were residents of Algete during 1995-1999. Although most of them had changed their residence and many have gone abroad, the investigators found a partial match (a 'familial case', probably a brother of the suspect) (Morcillo, Muñoz, 2015). The suspect was a resident of the French town of Pierrefountaine Les Varans (France). With the cooperation of the Gendarmerie he was arrested and soon extradited to Spain (2015). His DNA produced a genetic profile that completely matched that of the perpetrator. The Spanish Minister of Home Affairs said: "Guardia Civil never forgets a case". This is true, but most cases can be efficiently solved due to DNA techniques that allow obtaining an individual genetic profile and the use of a powerful tool, the police DNA databanks. Eva Blanco's case (a difficult case that later became cold) shows the versatility of the DNA analyses: it was possible to obtain the perpetrator's genetic profile, the search on different police DNA databanks (general or generated by a dragnet, and then the analysis of a 'familial search'), the ethnicity deduction from DNA markers (another interesting topic) and the international cooperation.

We want to conclude that criminal DNA databanks are really powerful investigation tools that allow solving easy (a direct match is often obtained) or difficult crimes (cold cases). The software developed for dealing with the DNA databanks also allows the so called 'familial searches' that in most cases have been the cornerstones for arresting dangerous murderers. Still several problems remain in their use: technical (false matches due to different circumstances), ethic and legal aspects (which are important and deserve special attention in the countries' legislation) or international cooperation (to share the information of DNA profiles stored in police databanks from different countries). This latter point is fundamental to properly fight organized crime and international terrorism, but this is a political problem, not a police force one. 


\section{References}

1. Ashcroft, J., Daniels, D.J., Hart, S.V. (2002). Using DNA to solve cold cases, NIJ Special Report, 1-24.

2. Asplen, C. (2014). DNA Databases. In D. Primorac \& M. Schanfield (Eds.), Forensic DNA applications. An interdisciplinary perspective (pp. 557-569). Boca Raton (FL) USA: CRC Press.

3. Barash, M., Reshef, A., Voskoboinik, L., Zamir, A., Motro, U., Gafny, R. (2012). A search for obligatory paternal alleles in a DNA database to find an alleged rapist in a fatherless paternity case, Journal of Forensic Sciences, 57: 1098-1101.

4. Barca, D.C. (2013). Familial DNA testing, House Bill 2261, and the need for Federal oversight, Hastings Law Journal, 64: 499-527.

5. Benschop, C.C.G., van de Merwe, L., de Jong, J., Vanvooren, V., Kempenaers, M., Kees van der Beek, C.P., Barni, F., Reyes, E.L., Moulin, L., Pene, L., Haned, H., Sijen, T. (2017). Validation of SmartRank: A likelihood ratio software for searching national DNA databases with complex DNA profiles, Forensic Science International: Genetics, 29: 145-153.

6. Bieber, F.R. (2006). Turning base hits into earned runs: improving the effectiveness of forensic DNA data bank programs, The Journal of Law, Medicine and Ethics, 34: 222-233.

7. Bieber, R.F., Brenner, C.H., Lazer, D. (2006). Finding criminals through DNA of their relatives, Science, 312: 1315-1316.

8. Buckleton, J.S., Bright, J.-A., Curran, J.M., Taylor, D. (2016). Validating databases. In J.S. Buckleton, J.-A.Bright \& D. Taylor (Eds.). Forensic DNA evidence interpretation. $2^{\text {nd }}$ ed. (pp. 133-180). Boca Raton (FL), USA: CRC Press.

9. Busher, L. (2002). The use of the U.K. National DNA Database to support an intelligence led approach to the investigation of crime, Journal of Forensic Medicine, 21-25.

10. Butler, J.M. (2005). Forensic DNA typing: Biology, technology and genetics of STR markers. $2^{\text {nd }}$ ed., Burlington (MA): Elsevier Academic Press.

11. Butler, J.M. (2010). Fundamentals of Forensic DNA typing. Burlington (MA): Elsevier Academic Press.

12. Butler, J.M. (2012). Advanced topics in Forensic DNA typing: Methodology. Waltham (MA): Academic Press.

13. Cale, C.M. (2015). Forensic DNA evidence is not infallible, Nature, 526: 611. 
14. Cale, C.M., Earll, M.E., Latham, K.E., Bush, G.L. (2016). Could secondary DNA transfer falsely place someone at the scene of a crime?, Journal of Forensic Sciences, 61: 196-203.

15. Cho, M.K., Sankar, P. (2004). Forensic genetics and ethical, legal and social implications beyond the clinic, Nature Genetics, 36 (11 Suppl.): S8-S12.

16. Comisión Nacional para el uso forense del ADN. (2011). Actividades 20092010, Ministerio de Justicia, Madrid, España.

17. Dundes, L. (2001). Is the American public ready to embrace DNA as a crime-fighting tool? A survey assessing support for DNA databases, Bulletin of Science, Technology \& Society, 21: 369-375.

18. Esmaili, S. (2007). Searching for a needle in a haystack: the constitutionally of police DNA dragnets, Chicago-Kent Law Review, 82: 495-523.

19. Feehan, C. (2016). DNA database linked burglar to 14 different crime scenes, Forensic Magazine, $4^{\text {th }}$ January 2016.

20. Fernandez, H.K. (2005). Genetic privacy, abandonment, and DNA dragnets: Is Fourth Amendment jurisprudence adequate?, The Hastings Center Report, 35: 21-23.

21. Figueredo, E. (2013). El ADN resuelve un brutal asesinato en Gavà 10 años después del caso, La Vanguardia, 31 $1^{\text {st }}$ January 2013.

22. Fung, W.K., Hu, Y.-Q. (2008). Statistical DNA Forensics. Theory, methods and computation, Chichester, (UK): John Wiley and Sons, Ltd.

23. Gamero, J.J., Romero, J.L., Peralta, J.L., Carvalho, M., Corte-Real, F. (2007). Spanish public awareness regarding DNA profile databases in forensic genetics: what type of DNA profiles should be included?, Journal Medical Ethics, 33: 598-604.

24. Gamero, J.J., Romero, J.L., Peralta, J.L., Corte-Real, F., Guillén, M., Anjos, M.J. (2008). A study of Spanish attitudes regarding the custody and use of forensic DNA databases, Forensic Science International: Genetics, 2: 138-149.

25. García, O., Crespillo, M., Yurrebaso, I. (2017). Suspects identification through "familial searching" in DNA databases of criminal interest. Social, ethical and scientific implications, Revista Española de Medicina Legal, 43: 26-34.

26. Gill, P., Fereday, L., Morling, N., Schneider, P.M. (2006a). The evolution of DNA databases - recommendations for new European STR loci, Forensic Science International, 156: 242-244.

27. Gill, P., Fereday, L., Morling, N., Schneider, P.M. (2006b). New multiplexes for Europe-amendments and clarification of strategic development, Forensic Science International, 163: 155-157. 
28. Gill, P., Haned, H., Bleka, O., Hansson, O., Dorum, G., Egeland, T. (2015). Genotyping and interpretation of STR-DNA: low template, mixtures and database matches - twenty years of research and development, Forensic Science International: Genetics, 18: 100-117.

29. Goodwin, W., Linacre, A., Hadi, S. (2007). An introduction to Forensic Genetics, Chichester, (UK): John Wiley and Sons, Ltd.

30. Grant, B. (2010). Slime and punishment, The Scientist, March 2010.

31. Harbison, S.A., Hamilton, J.F., Walsh, S.J. (2001). The New Zealand DNA databank: its development and significance as a crime solving tool, Science and Justice, 41: 33-37.

32. Heurich, C. (2008). Cold cases: resources for agencies, resolution for families, NIJ Journal, 260: 20-23.

33. Hunter, P. (2010). Anything you touch may be used against you, $E M B O$ Reports, 11: 424-427.

34. Innocence Project. (2016). Innocence position on familial searching DNA databases. In,: DNA technology in Forensic Science. Available at: http://anyflip.com/ouiz/qdzi/basic (28/06/18).

35. Jeffreys, A.J. (2005). Genetic fingerprinting, Nature Medicine, 11: 1035-1039.

36. Jeffreys, A.J., Brookfield, J.F.Y., Semeonoff, R. (1985). Positive identification of an immigration test-case using human DNA fingerprints, Nature, 317: 818-819.

37. Jeffreys, A.J., Wilson, V., Thein, S.L. (1985). Individual-specific 'fingerprints' of human DNA, Nature, 316: 76-79.

38. Kaye, D.H. (2010). The double helix and the law of evidence, Cambridge (MA), USA: Harvard University Press.

39. Kim, J., Mammo, D., Siegel, M.B., Katsanis, S.H. (2011). Policy implications for familial searching, Investigative Genetics, 2: 22.

40. Krimsky, S. (2011). Twenty years of DNA databanks in the U.S., GeneWatch, 24: 9-11.

41. Krimsky, S., Simoncelli, T. (2011). Genetic Justice, N.Y.: Columbia University Press.

42. Lovrich, N.P., Pratt, T.C., Gaffney, M.J., Johnson, C.L., Asplen, C.H., Hurst, L.H., Schellberg, T.M. (2004). National Forensic DNA Study Report. Final Report, U.S. Department of Justice, Washington, USA.

43. Machado, H., Silva, S. (2016). Voluntary participation in forensic DNA databases: altruism, resistance, and stigma, Science, Technology, \& Human Values, 41: 322-343. 
44. Martínez, J. (1997). Una estudiante que volvía de noche a casa muere apuñalada por la espalda, El País, 27 th April 1997.

45. Mestres, F., Vives-Rego, J. (2009). Bancos y bases de datos genéticos para usos forenses, Revista del Poder Judicial, 89: 239-263 (summary in English).

46. Michaelis, R.C., Flanders jr., R.G., Wulff, P.H. (2008). A litigator's guide to DNA. From the laboratory to courtroom, Burlington (MA): Elsevier Academic Press.

47. Miller, G. (2010). Familial DNA testing scores a win in serial killer case, Science, 329: 262.

48. Morcillo, C, Muñoz, P. (2015). Un hermano del asesino de Eva Blanco viajó hasta Tres Cantos para dar su ADN, $A B C, 11^{\text {th }}$ October 2015.

49. Reilly, P. (2001). Legal and public policy issues in DNA forensics, Nature Reviews Genetics, 2: 313-317.

50. Rothstein, M.A., Carnahan, S.J. (2001). Legal and policy issues in expanding the scope of law enforcement DNA data banks, Brooklyn Law Review, 67: 127-178.

51. Schneider, P.M., Martin, P.D. (2001). Criminal DNA databases: the European situation, Forensic Science International, 119: 232-238.

52. Schuster, B. (2008). Cold cases: strategies explored at NIJ regional trainings, NIJ Journal, 260: 24-26.

53. Simoncelli, T., Krimsky, S. (2007). A new era of DNA collections: At what cost to Civil Liberties?, American Constitution Society for Law and Policy, 2007: 1-19.

54. Strachan, T., Read, A. (2011). Human Molecular Genetics, $4^{\text {th }}$ ed. N.Y.: Garland Science.

55. Suter, S.M. (2010). All in the family: privacy and DNA familial searching, Harvard Journal of Law and Technology, 23: 310-399.

56. Tarín, S. (2012). La policía resuelve un asesinato ocurrido hace diez años en Tarragona, La Vanguardia, $8^{\text {th }}$ August 2012.

57. Van Camp, N., Dierickx, K. (2008). The retention of forensic DNA samples: a socio-ethical evaluation of current practices in the EU, Journal of Medical Ethics, 34: 606-610.

58. Van Oorschot, R.A.H., Jones, M.K. (1997). DNA fingerprints from fingerprints, Nature, 387: 767.

59. Walker, S. (2004). Police DNA 'sweeps' extremely unproductive, Dept. Criminal Justice, University of Nebraska at Omaha.

60. Wallace, H. (2006). The UK National DNA database: balancing crime detection, human rights and privacy, EMBO Reports, 7: S26-S30. 
61. Walsh, S.J., Bright, J.-A., Buckleton, J.S. (2016). DNA intelligence databases. In J.S. Buckleton, J.-A. Bright \& D. Taylor (Eds.), Forensic DNA evidence interpretation, $2^{\text {nd }}$ ed. (pp. 429-445). Boca Raton (FL) USA: CRC Press.

62. Walsh, S.J., Curran, J.M., Buckleton, J.S. (2010). Modeling forensic DNA database performance, Journal of Forensic Sciences, 55: 1174-1183.

63. Werrett, D.J. (1997). The National DNA Database, Forensic Science International, 88: 33-42.

64. Wiegand, P., Budowle, B., Rand, S., Brinkmann, B. (1993). Forensic validation of the STR systems SE33 and TC11, International Journal of Legal Medicine, 105: 315-320.

65. Zadok, E. (2010). Legislative and ethical questions regarding DNA and other forensic 'biometric' databases. In A. Kumar \& D. Zhang (Eds.), Ethics and Policy of Biometrics (pp. 27-39). Berlin: Springer Verlag.

\section{Internet webpages}

1. BBC News, available at: http://news.bbc.co.uk/go/pr/fr/-/1/hi/england/3639057.stm (27/06/2018).

2. CODIS - NDIS Statistics, available at: https://www.fbi.gov/services/laboratory/biometric-analysis/codis/ndis-statistics (27/06/2018).

3. ENFSI DNA Working Group, DNA database management review and recommendations, 2017, available at: http://enfsi.eu/wp-content/uploads/2017/09/DNA-databasemanagement-review-and-recommendatations-april-2017.pdf (27/06/18).

4. Europe 1, available at: http://www.europe1.fr/faits-divers/le-voleur-trahipar-un-bisou-1791045 (27/06/2018).

5. Le Parisien, available at: http://www.leparisien.fr/espace-premium/fait-dujour/la-vie-tranquille-d-un-employe-fan-de-cluedo-13-09-2014-4130923. php (27/06/2018).

6. National DNA Database statistics 2017, available at: https://www.gov.uk/ government/statistics/national-dna-database-statistics (27/06/2018).

7. NCR.nl, available at: http://www.nrc.nl/nieuws/2012/11/19/na-dertienjaar-een-doorbraak-de-belangrijkste-momenten-in-de-zaak-vaatstra (27/06/2018).

8. Swissinfo.ch available at: http://www.swissinfo.ch/eng/mass-dna-testingto-start-in-rape-case/41737028 (27/06/2018). 


\section{PRIMENE DNK BANKE PODATAKA KAO ISTRAŽNOG SREDSTVA U REŠAVANJU KRIVIČNIH PREDMETA}

\section{Fransesk Mestres}

Odeljenje za genetiku, Univerzitet u Barseloni, Španija

\section{Goran Živanović \\ Odeljenje za genetiku, Institut za biološka istraživanja "Siniša Stanković” Univerzitet u Beogradu}

Sažetak: Uvođenje molekularnih markera, kao što je STR - kratka tandemska ponavljanja, predstavljalo je ključni događaj u forenzičkoj genetici. Time je omogućeno dobijanje individualnih genetskih profila na osnovu kojih su se pojedinci mogli pravilno identifikovati s malom verovatnoćom greške. Pored toga, policijski istražitelji su ubrzo postali svesni koristi koju za istragu obezbeđuju DNK banke podataka, definisane kao zbirka individualnih DNK profila koja se uglavnom upotrebljava za istraživanje krivičnih dela i identifikaciju osumnjičenih. U ovom radu, autori prikazuju najuobičajenije načine korišćenja tih policijskih DNK banaka podataka, komentarišući njihove nedostatke i kako da se prevaziđu. Korišćenje i značaj policijskih DNK banaka podataka u specifičnim krivičnim predmetima takodje se objašnjavaju: zaboravljeni (tzv. hladni) slučajevi (engl. cold cases), istrage na osnovu krvnog srodstva i potrage za počiniocem. Upravo se ove tri specifične vrste predmeta opisuju i razmatraju u radu. Ukratko, iako izvesni tehnički, etičko-pravni i međunarodni aspekti moraju da se poboljšaju, policijske DNK banke podataka su zaista moćno sredstvo istrage koje doprinosi rešavanju velikog broja krivičnih predmeta.

Ključne reči: forenzička genetika, DNK profil, DNK banka podataka, zaboravljeni slučaj, istraga na osnovu krvnog srodstva, potraga za počiniocem. 